\author{
Michal Comporek \\ University of Lodz, Department of Business Analysis and Strategy \\ e-mail:michal.comporek@uni.lodz.pl \\ ORCID: 0000-0002-1402-2505
}

\title{
THE EFFECTIVENESS OF THE BENEISH MODEL IN THE DETECTION OF ACCOUNTING VIOLATIONS - THE EXAMPLE OF COMPANIES SANCTIONED BY THE POLISH FINANCIAL SUPERVISION AUTHORITY
}

DOI: $10.15611 /$ pn.2020.10.02

JEL Classification: G30, M41, M42

(C) 2020 Michał Comporek

This work is licensed under the Creative Commons Attribution-ShareAlike 4.0 International License. To view a copy of this license, visit http://creativecommons.org/licenses/by-sa/4.0/

Quote as: Comporek, M. (2020). The effectiveness of the Beneish model in the detection of accounting violations - the example of companies sanctioned by the Polish Financial Supervision Authority. Prace Naukowe Uniwersytetu Ekonomicznego we Wroctawiu, 64(10).

\begin{abstract}
The main purpose of the paper is to assess the effectiveness of the eight-factor Beneish model in detecting manipulations in the financial statements of public companies listed on the Warsaw Stock Exchange. The research sample consists of 27 enterprises that were sanctioned at least once by the PFSA for irregularities in compliance with the IAS/ IFRS principles in the period 2006-2018. Empirical analysis proved that in the selected group of enterprises, the original version of the Beneish model is characterized by a relatively low degree of usefulness, thus it should be considered as an average tool supporting the work of auditors, statutory auditors and stock exchange investors, and at the same time a starting point for the further search for instruments to detect accounting violations, developed and adapted to conditions of the Polish capital market.
\end{abstract}

Keywords: Beneish model, Polish Financial Supervision Authority, Warsaw Stock Exchange, accounting violations.

\section{Introduction}

A true and objective view of a company's financial standing should be reflected in the financial statements prepared in accordance with the current accounting standards, and in the event of any deviations from these guidelines - including their justification 
and description. This image should be presented in uniform layouts and verified by an independent body. In the case of companies listed on the Warsaw Stock Exchange, the Polish Financial Supervision Authority (PFSA) is one of such bodies ensuring the proper fulfillment of disclosure obligations by issuers of securities. Although the highest standards in accounting reporting are expected from public companies, business practice has shown that there are cases in which the PFSA not only raises reservations, but also imposes severe financial and legal sanctions in connection with non-compliance with the IAS/IFRS guidelines.

At the same time, apart from the opinions of the PFSA and statutory auditors, the stakeholders of public companies are still looking for effective tools for a relatively quick assessment of the credibility of the information contained in the company's financial statements. This is particularly important from the perspective of decision-making processes aimed at, among others, the possibility of a rapid increase in cash by implementing investments with above-average rates of return. In the literature on the subject, it is noted that such instruments include the analysis of discretionary accruals (Dechow and Dichev 2002; Healy and Wahlen 1999; Jones, 1991; Piosik, 2013, Schipper, 1989, etc.) or the analysis of red flags (Arshad, Asyiqin, Razali, and Abu Bakar, 2015; DiNapoli, 2016; Lew, 2017; Njanike, Dube, and Mashayanye, 2009; Pincus, 1989, etc.). However, also discriminatory models reducing the assessment of the reliability of reporting data to the analysis of a single indicator, combining various economic measures in a weighted manner, may prove helpful in assessing the quality of financial statements (Fich and Shivdasani, 2007; Kaminski, Wetzel, and Guan, 2004; Skousen and Twedt, 2009). The best known of these is the Beneish probit model, which assumes that on the basis of selected variables appearing in the financial statements, it can be assessed whether the company has manipulated its financial results, understood as a breach of the accepted accounting standards (Beneish, 1999).

The main purpose of the study is to analyse the effectiveness of the eight-variable Beneish M-Score model in assessing the credibility of the reporting data contained in the financial reports of public companies listed on the Warsaw Stock Exchange in 2006-2018. The research sample included 27 enterprises which, in the adopted reference period, were fined at least once by the PFSA in the context of compliance with IAS/IFRS principles. Empirical research focused mainly on the answer to the question of what percentage of the examined enterprises the classic Beneish model allowed for the correct classification of the company to the group of manipulators based on the data from the year in which the irregularities were concerned. Moreover, the paper tested whether in the studied sample the statistical distribution of the financial indicators used in the Beneish model in the preceding periods differed statistically significantly from the values of those measures calculated for the period, up to when the irregularities were found.

Empirical research was carried out on the basis of data periodically published by the PFSA and financial information taken from the Notoria Serwis SA database. A more detailed description of the research methodology is provided in a further part of the paper. 


\section{Applying the Beneish model in economic practice - a literature review}

As indicated in the introduction of the paper, the Beneish model is one of the best known methods of detecting accounting manipulations in the world. Developed in 1999, the eight-variable Beneish M-Score model is based on financial analyses of 74 companies designated by the US Securities and Exchange Commission (SEC) as manipulators and 2,332 public non-manipulators, and covers the period 1982-1992. From an instrumental point of view, Beneish relied on measures that present future business performance, indicators related to cash flow and accruals as well as measures that characterize managers' motivation to manipulate data (Beneish, 1999, p. 24). The conducted research allowed for identification of about half of the companies involved in earnings manipulation prior to public discovery.

Since then, accounting researchers all over the world have also found the power of the M-Score model from different points of view (Ahn and Lihn, 2016, p. 17). From the perspective of the Polish capital market, the research by Golec (2019, pp. 161-182) deserves special attention. That author gathered evidence that the correctness of the classification of Polish companies with problems with the credibility of financial statements (based on the M-Score level of -2.22) was higher than in the case of the research conducted for the British market, but lower than for the Indonesian or Malaysian markets. In terms of the correct classification of enterprises belonging to the group of non-manipulators on the Polish market, the Beneish model proved to be weak, as its $75 \%$ correctness in this area was lower than in the case of other authors, where it exceeded $80 \%$ each time. The issue of the usefulness of the Beneish model in detecting accounting manipulations using the example of the Polish market is also addressed in the study by Dalecka (2015, pp. 1-9), although it focuses mainly on the theoretical aspects of using the M-Score model in economic practice.

Citing other, selected results of empirical research on the usefulness of the Beneish model in detecting accounting manipulations, it is worth noting that some researchers applied the original eight-variable M-Score model for earnings management testing (Franceschetti and Koschtial 2013, pp. 1-22; Golec, 2019, pp. 161-182; Kaur, Sharma, and Khanna, 2013, pp. 11-18; Paolone and Magazzino, 2014, pp. 253-261) while others extended the model by adding some more variables (Marinakis, 2011; Dechow, Ge, Larson, and Sloan, 2011, pp. 17-82; Grove and Basilico, 2008, pp. 10-42). An approach frequently encountered in the literature on the subject is the use of the Beneish model to estimate the scale of the manipulation of accounting data in various economies. In this way, among the entire research sample, alleged manipulators and non-manipulators of financial statements are selected. Some of the studies carried out concern comparisons in terms of shaping the M-Score models in companies that were (or were not) considered as manipulators in a given period by capital market supervisory institutions. On the other hand, other researchers focused their attention only on individual enterprises, calculating the 
values of financial ratios for the periods in which accounting violations did or did not occur (see: Table 1).

Table 1. Selected results of empirical research on the usefulness of the Beneish model in distinguishing companies susceptible to accounting manipulations

\begin{tabular}{|c|c|c|}
\hline Authors & Sample & Main findings \\
\hline $\begin{array}{l}\text { Grove and } \\
\text { Basilico (2008) }\end{array}$ & $\begin{array}{l}\text { Sample consisting of } 120 \\
\text { manipulators and } 67,366 \\
\text { non-manipulators from } \\
\text { the USA with reference } \\
\text { period } 1986-2001\end{array}$ & $\begin{array}{l}\text { The accuracy of the Beneish model reached } 76 \% \text { in the } \\
\text { first year of using fraudulent methods, and } 66 \% \text { in the } \\
\text { second year after the year of using manipulative techni- } \\
\text { ques. The authors proposed to shift the M-Score level } \\
\text { to }-1.99\end{array}$ \\
\hline $\begin{array}{l}\text { Mahama } \\
(2015)\end{array}$ & Enron Corporation & $\begin{array}{l}\text { The paper finds that the fraudulent acts of the company } \\
\text { could have been detected as early as in 1997, long be- } \\
\text { fore its actual filing for bankruptcy in } 2001\end{array}$ \\
\hline $\begin{array}{l}\text { Tarjo and } \\
\text { Herawati } \\
(2015)\end{array}$ & $\begin{array}{l}\text { The data used in the } \\
\text { study were } 35 \text { companies } \\
\text { that committed fraud and } \\
35 \text { non-fraud companies } \\
\text { in Indonesia }\end{array}$ & $\begin{array}{l}\text { The results showed that overall the Beneish M-Score } \\
\text { model was capable of detecting financial fraud. Gross } \\
\text { margin index, depreciation index, index of sales and } \\
\text { general administrative burden and total accruals were all } \\
\text { significant in detecting financial fraud. The sales index, } \\
\text { asset quality index, and leverage index were statistically } \\
\text { not significant in detecting financial fraud. Moreover, } \\
\text { the analyses showed that } 77 \% \text { of manipulators and } 80 \% \\
\text { of non-manipulators were correctly classified using the } \\
\text { eight-factor Beneish model }\end{array}$ \\
\hline $\begin{array}{l}\text { Ahmed and } \\
\text { Naima (2016) }\end{array}$ & $\begin{array}{l}\text { Sample of } 102 \text { publicly } \\
\text { listed and non-financial } \\
\text { firms in Bangladesh from } \\
\text { the years } 2010 \text { to } 2013\end{array}$ & $\begin{array}{l}\text { The outcome of the M-Scores reveals that the propor- } \\
\text { tion of likely manipulator firms declined over the years. } \\
\text { The result of the independent } t \text {-test shows that inflating } \\
\text { revenues, capitalising expenses, and overstating intan- } \\
\text { gibles could serve as signals of earnings manipulation } \\
\text { by firms in Bangladesh }\end{array}$ \\
\hline $\begin{array}{l}\text { Ahn and Lihn } \\
(2016)\end{array}$ & $\begin{array}{l}\text { Sample of } 229 \text { non- } \\
\text {-financial Vietnamese } \\
\text { companies listed on the } \\
\text { HOSE during 2013-2014 }\end{array}$ & $\begin{array}{l}\text { The results showed that } 48.4 \% \text { non-financial Vietnam- } \\
\text { ese companies listed on the HOSE were involved in } \\
\text { earnings management. Generally, the M-Score model } \\
\text { could be considered to fit with sample observations in } \\
\text { Vietnam }\end{array}$ \\
\hline $\begin{array}{l}\text { Dbouk and } \\
\text { Zaaraour } \\
(2017)\end{array}$ & $\begin{array}{l}\text { The Data sets consist } \\
\text { of fifty three (53) } \\
\text { financial statements } \\
\text { acquired from largest } \\
\text { corporations over four } \\
\text { consecutive years } \\
(2006-2019)\end{array}$ & $\begin{array}{l}\text { The Beneish Model produced best sensitivity (as } \\
\text { compared to Manual Auditors' Methods) in assessing } \\
\text { financial data for detecting earnings manipulation. } \\
\text { Authors revealed a classification rate of } 86.84 \% \text { using } \\
\text { the Beneish Model and } 60.53 \% \text { using Manual Auditors' } \\
\text { Methods }\end{array}$ \\
\hline
\end{tabular}

Source: own study based on (Ahmed and Naima, 2016, pp. 59-81; Ahn and Lihn, 2016, pp. 14-23; Dbouk and Zaaraour, 2017, pp. 172-179; Grove and Basilico, 2008, pp. 10-42; Mahama, 2015, pp. 1-18; Tarjo and Herawati, 2015, pp. 924-930). 


\section{Research methodology and sample selection}

The original eight-variable Beneish M-Score model consists in financial ratios that included: Days Sales in Receivable Index (DSRI), Gross Margin Index (GMI), Asset Quality Index (AQI), Sales Growth Index (SGI), Depreciation Index (DEPI), Sales, General and Administrative Index (SGAI), Leverage Index (LVGI) and Total Accruals to Total Assets (TATA). It takes the following formula:

$$
\begin{aligned}
\mathrm{M}=4.840 & +0,920 \times \mathrm{DSRI}+0,528 \times \mathrm{GMI}+0,0404 \times \mathrm{AQI}+0,892 \times \mathrm{SGI}+0,115 \\
& \times \mathrm{DEPI}-0,172 \times \mathrm{SGAI}+4,679 \times \mathrm{TATA}-0,327 \times \mathrm{LVGI},
\end{aligned}
$$

where:

- DSRI is measured as the ratio of days' sales in receivables in year $t$ to year $t-1$;

- GMI is calculated as the ratio of gross margin in year $t-1$ to gross margin in year $t$;

- AQI is measured as the ratio of non-current assets other than plant, property and equipment to total assets in year $t$ to year $t-1$;

- SGI is computed as the ratio of Total Sales in year $t$ to Total Sales in year $t-1$;

- DEPI is measured as the ratio of the rate of depreciation in year $t-1$ to the corresponding rate in year $t$;

- SGAI is calculated as the ratio of SGA expenses in year $t$ relative to year $t-1$;

- LVGI is the ratio of total debt to total assets in year $t$ relative to year $t-1$;

- TATA is computed as the Ratio of Total Accruals of year $t$ to Total Assets in year $t$. The obtained M-Score is then compared with the cut-off value which depends on the accepted level of errors of the first and second type, i.e. respectively: failure to show manipulation when it actually occurred, or indication of manipulation when it did not take place (Golec, 2019, p. 168). If the M-Score $>-2.22$, it shows indications of financial fraud within companies. In cases where the value of a given indicator could not be calculated due to the presence of zero values in the denominator of the fraction, the observation was not eliminated and the indicator was assigned "neutral" values equal to 1 (Beneish, 1999, p. 27). It is also important that the company under consideration in the period $t-1$ could not manipulate accounting data. Hence, if the manipulations of the reported results in the company were made continuously for more than one financial year, the first of the periods for which irregularities were detected was used for further analysis.

Empirical research was carried out among 27 public companies listed on the WSE that had been fined at least once by the PFSA in the context of compliance with IAS/IFRS principles in the period 2006-2018. Additionally, the sample selection was based on the following criteria:

- the fiscal year of the firm should end up to 31 December;

- the company did not conduct business activity in the finance and insurance sectors;

- all of the required financial data must be available. 
When selecting the financial statements of issuers for periodic analysis by the PFSA, the high priority granted to the criterion of qualifications in the audit reports, disclaimer of opinion or negative opinion is maintained. The presence of reservations in the reports on the review of the semi-annual financial statements, refusal to express a conclusion or negative conclusions was also taken into account (Polish Financial Supervision Authority [PFSA], 2018). The analysis of the most important offences committed by public companies listed on the WSE in connection with the violation of IAS/IFRS principles allows to emphasize that the vast majority of sanctions imposed by the PFSA were related to non-compliance with:

- IAS 1 - Presentation of financial statements;

- IAS 2 - Inventories;

- IAS 8 - Accounting Policies, Changes in Accounting Estimates and Errors;

- IAS 11 - Construction contracts;

- IAS 12 - Income Taxes;

- IAS 20 - Government Grants and Disclosure of Government Assistance;

- IAS 28 - Investments in Associates;

- IAS 34 - Interim Financial Reporting;

- IAS 36 - Impairment of Assets;

- IAS 37 - Provisions, Contingent Liabilities and Contingent Assets;

- IAS 38 - Intangible Assets;

- IAS 39 - Financial Instruments: Recognition and Measurement;

- IFRS 2 - Share-based Payment;

- IFRS 3 - Business Combinations;

- IFRS 7 - Financial Instruments: Disclosures;

- IFRS 8 -Operating Segments;

- IFRS 10 - Consolidated and separate financial statements (see: Table 2).

At the same time it can be noted that both the spectrum of committed offences and the nature of the sanctions imposed clearly differed in the analysed research sample. In four cases the PFSA applied (apart from the financial penalty) the indefinite exclusion of securities from trading on the regulated market. Usually, individual enterprises recorded more than one type of misconduct with regard to irregularities related to IAS/IFRS, while some companies were punished more than once.

Another important comment is the fact that the control sample was not included in the research. By assigning a pair to enterprises from the group of manipulators, it is not always possible to choose a company similar enough to reflect all the features that may affect the scope of manipulation. The sample firms maintain individualized performance patterns over time and even companies within a branch of the industry have varying characteristics. 
Table 2. List of companies fined by the PFSA for non-compliance with IAS/IFRS guidelines

\begin{tabular}{|c|c|c|}
\hline Company & Year of the inaccuracies & Violated IAS/IFRS \\
\hline Advadis SA & 2010,2011 & not specified \\
\hline Atlanta Poland SA & 2009 & not specified \\
\hline ATM Grupa SA & 2006 & not specified \\
\hline Alma Market SA & 2016 & IAS 1, IAS 34, IAS 36, IFRS 7 \\
\hline B3System SA & 2014,2015 & IAS 1, IAS 24, IFRS 7, IFRS 8 \\
\hline Calatrava Capital SA & $2012,2013,2014$ & $\begin{array}{l}\text { IFRS } 7 \text {, IFRS 10, IAS 28, IAS 34, IAS } \\
\text { 36, IAS } 39\end{array}$ \\
\hline CFI Holding SA & 2012,2014 & IFRS 3 \\
\hline $\begin{array}{l}\text { Dolnośląskie Surowce } \\
\text { Skalne SA }\end{array}$ & 2011,2012 & IAS 2, IAS 11, IAS 34, IAS 36 \\
\hline Energomontaż Południe SA & 2011,2012 & IAS 1 , IAS 37 \\
\hline Gant SA & 2012, 2013, 2014 & IAS 34, IAS 39, IFRS 7 \\
\hline Hawe SA & 2014, 2015, 2016, 2017 & IAS 1 , IAS 12 , IAS 34 , IAS 36, IFRS 7 \\
\hline $\begin{array}{l}\text { Huta Szkła Gospodarczego } \\
\text { Irena SA }\end{array}$ & $2008,2009,2010$ & not specified \\
\hline KBDom SA & 2010 & IFRS 3, IFRS 7 \\
\hline Kerdos SA & $2013,2014,2015$ & IAS 34, IAS 36, IAS 38, IFRS 3, IFRS 7 \\
\hline Macrologic SA & 2009 & IFRS 2 \\
\hline Mewa SA & 2009,2010 & IAS 34, IAS 36, IFRS 3 \\
\hline MNI SA & 2008,2010 & not specified \\
\hline Mostostal Warszawa SA & 2011,2012 & IAS 11 \\
\hline MSX Resources SA & $2012,2013,2014$ & $\begin{array}{l}\text { IAS } 28 \text {, IAS 34, IAS 39, IFRS 3, IFRS 7, } \\
\text { IFRS } 10\end{array}$ \\
\hline One-to-One SA & $2011,2012,2013$ & IAS 1, IAS 36, IAS 37 \\
\hline PBG SA & 2011,2012 & IAS 1, IAS 36, IFSR 7 \\
\hline Petrolinvest SA & $\begin{array}{l}\text { 2008, 2009, 2010, 2011, } \\
\text { 2013, 2014, } 2015\end{array}$ & IAS 1, IAS 34, IAS 39, IFRS 3 \\
\hline PMPG SA & $2008,2009,2010$ & IAS 28, IAS 34, IAS 36, IFRS 3, IFRS 10 \\
\hline Polimex Mostostal SA & 2011 & IAS 11, IAS 37, IFRS 7 \\
\hline Radpol SA & $2009,2010,2011$ & IAS 8, IAS 20, IFRS 3 \\
\hline Solar Company SA & 2011, 2012, 2013 & IAS 1 , IAS 27, IFRS 7 \\
\hline Żywiec SA & 2009,2010 & IFRS 8 \\
\hline
\end{tabular}

Source: own study based on (PFSA, 2018). 


\section{Empirical results}

In order to assess the effectiveness of the original version of Beneish model for issuers from the stock market, it was assumed that the cut-off point would be the M-Score of -2.22 . Table 3 presents the calculated values of the M-Score for the periods in relation to which the PFSA found irregularities in compliance with the IAS/ IFRS principles, as well as for the previous periods. Observations correctly classified for M-Score are marked in grey. It should be emphasized that there are significant disproportions in the shaping of the M-Score in the examined sample. This remark applies in particular to the following periods: $t-2$ and $t-1$, for which the statistical range of the M-Score indicator was (respectively): 920.12 and 170.20.

Table 3. M-Score values computed for the tested group of companies

\begin{tabular}{|c|c|c|c|c|c|}
\hline \multirow[t]{2}{*}{ Company } & \multicolumn{2}{|c|}{$\begin{array}{l}\text { Periods for which } \\
\text { no accounting } \\
\text { manipulations were } \\
\text { detected }\end{array}$} & \multirow{2}{*}{$\begin{array}{c}\text { Period } \\
\text { for which } \\
\text { accounting } \\
\text { manipulations } \\
\text { were detected } \\
\mathrm{T}\end{array}$} & \multicolumn{2}{|c|}{ Relative gain } \\
\hline & $t-2$ & $t-1$ & & $t / t-2$ & $t / t-1$ \\
\hline 1 & 2 & 3 & 4 & 5 & 6 \\
\hline Advadis SA & 916.427 & -1.448 & -3.721 & -1.004 & 1.569 \\
\hline Alma Market SA & -2.573 & -3.710 & -6.448 & 1.506 & 0.738 \\
\hline Atlanta Poland SA & -3.249 & 8.142 & -3.116 & -0.041 & -1.383 \\
\hline ATM Grupa SA & $\mathrm{n} / \mathrm{a}$ & $\mathrm{n} / \mathrm{a}$ & -2.061 & $\mathrm{n} / \mathrm{a}$ & $\mathrm{n} / \mathrm{a}$ \\
\hline B3System SA & -2.314 & -8.284 & -2.069 & -0.106 & -0.750 \\
\hline Calatrava Capital SA & 98.710 & -3.907 & -14.396 & -1.146 & 2.685 \\
\hline CFI Holding SA & -2.187 & -6.608 & -5.299 & 1.423 & -0.198 \\
\hline $\begin{array}{l}\text { Dolnośląskie Surowce } \\
\text { Skalne SA }\end{array}$ & -2.268 & -1.452 & -9.200 & 3.056 & 5.338 \\
\hline Energomontaż Południe SA & -2.564 & -2.816 & -3.098 & 0.208 & 0.100 \\
\hline Gant SA & 5.608 & -1.866 & -6.467 & -2.153 & 2.465 \\
\hline Hawe SA & -2.880 & -8.852 & 2.055 & -1.714 & -1.232 \\
\hline $\begin{array}{l}\text { Huta Szkła Gospodarczego } \\
\text { Irena SA }\end{array}$ & -2.889 & -3.056 & -6.039 & 1.091 & 0.976 \\
\hline KBDom SA & -3.697 & 7.695 & -8.565 & 1.317 & -2.113 \\
\hline Kerdos SA & 34.779 & 3.856 & -1.668 & -1.048 & -1.433 \\
\hline Macrologic SA & -2.856 & -3.231 & -2.603 & -0.089 & -0.194 \\
\hline Mewa SA & -0.248 & -3.640 & -0.037 & -0.850 & -0.990 \\
\hline MNI SA & -1.975 & -0.475 & 0.714 & -1.362 & -2.502 \\
\hline Mostostal Warszawa SA & -2.911 & -1.943 & -2.804 & -0.037 & 0.444 \\
\hline
\end{tabular}


Table 3, cont.

\begin{tabular}{|l|r|r|r|r|r|}
\hline \multicolumn{1}{|c|}{1} & \multicolumn{1}{c|}{2} & \multicolumn{1}{c|}{3} & \multicolumn{1}{c|}{4} & \multicolumn{1}{c|}{5} & \multicolumn{1}{c|}{6} \\
\hline MSX Resources SA & -2.760 & -4.581 & -0.386 & -0.860 & -0.916 \\
\hline One-to-One SA & -1.467 & -3.531 & -2.078 & 0.417 & -0.411 \\
\hline PBG SA & -2.409 & -2.427 & -1.967 & -0.183 & -0.190 \\
\hline Petrolinvest SA & $\mathrm{n} / \mathrm{a}$ & -2.648 & -3.967 & $\mathrm{n} / \mathrm{a}$ & 0.498 \\
\hline PMPG SA & 63.899 & 179.051 & -0.423 & -1.007 & -1.002 \\
\hline Polimex Mostostal SA & -3.284 & -2.282 & -5.263 & 0.603 & 1.307 \\
\hline Radpol SA & -2.358 & -0.604 & -2.560 & 0.086 & 3.239 \\
\hline Solar Company SA & $\mathrm{n} / \mathrm{a}$ & $\mathrm{n} / \mathrm{a}$ & -1.095 & $\mathrm{n} / \mathrm{a}$ & $\mathrm{n} / \mathrm{a}$ \\
\hline Żywiec SA & -2.783 & -2.535 & -2.651 & -0.048 & 0.046 \\
\hline
\end{tabular}

Source: own study.

Referring to the results of empirical research on period $t$, it should be noted that the tested model poorly identified the problem of accounting violations. For the period for which irregularities were detected, the Beneish model correctly verified 11 out of 27 surveyed companies. The situation is only slightly better with regard to the accounting periods preceding year $t$. In the $t-2$ period, for 9 out of 24 enterprises, the value of the indicator was above the threshold value, while for the $t-1$ period, such a situation was noted for 9 out of 25 observations. Only in the case of the following companies: B3System SA, Hawe SA, MSX Resources SA and PBG SA, did the tested model turn out to correctly classify a given company among manipulators (non-manipulators) in each of the three analysed accounting years.

The results of the research show in Table 4 that the eight-factor Beneish model allowed for correct verification of $40.74 \%$ of companies that turned out to be manipulators in period $\mathrm{t}$, as well as $63.27 \%$ of companies that did not make accounting violations in periods: $t-2$ and $t-1$. No apparent difference in the calculated index M-Score in the periods $t-2, t-1$ and $t$ can be explained by the fact that the possibility of implementing accounting intervention in the external financial reporting process may be highly dependent on the existence of particular business conditions which appear in subsequent accounting periods. What is more, it should be pointed out that the Notoria Serwis SA database, which is the main source of accounting data used in the paper, could contain data after the auditor's correction. This premise could also influence the final results of the research.

In order to evaluate whether the values of the M-Score indicators (as well as the eight partial financial ratios used in their estimation) differed in a statistically significant manner in individual periods, the non-parametric Wilcoxon signed rank test was used. The adopted null hypothesis (H0) assumed that there were no differences between the measurements in the tested accounting years, and the alternative hypothesis (H1) stated that the tested indicators values would statistically 
Table 4. Effectiveness of the classification of tested companies using the Beneish model for the adopted M-Score level $=-2.22$

\begin{tabular}{|l|l|l|}
\hline Model & \multicolumn{1}{|c|}{$\begin{array}{c}\text { Periods for which } \\
\text { manipulations were detected }\end{array}$} & $\begin{array}{c}\text { Periods for which } \\
\text { manipulations were detected }\end{array}$ \\
\hline $\begin{array}{l}\text { Periods for which manipulations } \\
\text { were detected }\end{array}$ & $\begin{array}{l}\text { True positive indications - } \\
\mathbf{4 0 . 7 4 \%}\end{array}$ & $\begin{array}{l}\text { Type I error }- \text { false positive } \\
\text { indications }-36.73 \%\end{array}$ \\
\hline $\begin{array}{l}\text { Periods for which no } \\
\text { manipulations were detected }\end{array}$ & $\begin{array}{l}\text { Type II error }- \text { false negative } \\
\text { indications }-\mathbf{5 9 . 2 6 \%}\end{array}$ & $\begin{array}{l}\text { True negative indications - } \\
\mathbf{6 3 . 2 7 \%}\end{array}$ \\
\hline
\end{tabular}

Source: own study.

differ in the adopted reference years. The analysis of empirical research shows that the alternative hypothesis was confirmed only in one case (comparison of M-Score values for periods $t-2$ and $t$ and also for periods $t-1$ and $t$ ). In the remaining cases, no grounds were found to reject the $\mathrm{H} 0$ hypothesis in favour of the alternative $\mathrm{H} 1$ hypothesis (Table 5).

Table 5. Parameters of the distributions of the M-Score values and individual financial indicators used in the Beneish model in the analysed subperiods

\begin{tabular}{|c|c|c|c|c|c|c|c|c|}
\hline \multirow{3}{*}{ Variable } & \multirow{3}{*}{ Periods } & \multirow{2}{*}{\multicolumn{3}{|c|}{ Distribution statistics }} & \multicolumn{4}{|c|}{$\begin{array}{l}\text { Wilcoxon signed rank test - } \\
\text { periods compared }\end{array}$} \\
\hline & & & & & \multicolumn{2}{|c|}{$t / t-2$} & \multicolumn{2}{|c|}{$t / t-1$} \\
\hline & & Mean & Median & $\begin{array}{c}\text { Std. } \\
\text { deviation }\end{array}$ & $Z$ & $p$ & $Z$ & $p$ \\
\hline 1 & 2 & 3 & 4 & 5 & 6 & 7 & 8 & 9 \\
\hline \multirow{3}{*}{$A Q I$} & $t-2$ & 6.69 & 1.06 & 20.42 & \multirow{3}{*}{-0.39} & \multirow{3}{*}{0.70} & \multirow{3}{*}{-0.57} & \multirow{3}{*}{0.57} \\
\hline & $t-1$ & 2.82 & 0.97 & 5.41 & & & & \\
\hline & $t$ & 1.44 & 1.01 & 1.32 & & & & \\
\hline \multirow{3}{*}{$D E P I$} & $t-2$ & 4.49 & 0.99 & 17.11 & \multirow{3}{*}{-0.26} & \multirow{3}{*}{0.79} & \multirow{3}{*}{-1.07} & \multirow{3}{*}{0.29} \\
\hline & $t-1$ & 0.91 & 0.97 & 0.49 & & & & \\
\hline & $t$ & 0.96 & 0.92 & 0.38 & & & & \\
\hline \multirow{3}{*}{ DSRI } & $t-2$ & 8.24 & 1.09 & 25.67 & \multirow{3}{*}{-1.02} & \multirow{3}{*}{0.30} & \multirow{3}{*}{-0.54} & \multirow{3}{*}{0.59} \\
\hline & $t-1$ & 1.74 & 0.98 & 3.38 & & & & \\
\hline & $t$ & 1.25 & 1.03 & 0.99 & & & & \\
\hline \multirow{3}{*}{ GMI } & $t-2$ & 1.49 & 0.91 & 3.21 & \multirow{3}{*}{-0.20} & \multirow{3}{*}{0.84} & \multirow{3}{*}{-1.02} & \multirow{3}{*}{0.31} \\
\hline & $t-1$ & 1.32 & 0.80 & 3.74 & & & & \\
\hline & $t$ & 0.85 & 0.96 & 2.85 & & & & \\
\hline \multirow{3}{*}{$L V G I$} & $t-2$ & 1.64 & 1.03 & 2.42 & \multirow{3}{*}{-0.39} & \multirow{3}{*}{0.70} & \multirow{3}{*}{-0.93} & \multirow{3}{*}{0.35} \\
\hline & $t-1$ & 2.43 & 1.07 & 4.47 & & & & \\
\hline & $t$ & 1.22 & 1.06 & 0.81 & & & & \\
\hline
\end{tabular}


Table 5, cont.

\begin{tabular}{|c|c|c|c|c|c|c|c|c|}
\hline 1 & 2 & 3 & 4 & 5 & 6 & 7 & 8 & 9 \\
\hline \multirow{3}{*}{$S G A I$} & $t-2$ & 0.96 & 1.03 & 0.39 & \multirow{3}{*}{-0.25} & \multirow{3}{*}{0.81} & \multirow{3}{*}{-0.30} & \multirow{3}{*}{0.75} \\
\hline & $t-1$ & 1.12 & 0.96 & 0.51 & & & & \\
\hline & $t$ & 1.45 & 1.01 & 2.00 & & & & \\
\hline \multirow{3}{*}{$S G I$} & $t-2$ & 44.46 & 1.09 & 211.36 & \multirow{3}{*}{-0.70} & \multirow{3}{*}{0.48} & \multirow{3}{*}{-0.66} & \multirow{3}{*}{0.56} \\
\hline & $t-1$ & 9.27 & 1.23 & 40.99 & & & & \\
\hline & $t$ & 1.21 & 1.02 & 1.16 & & & & \\
\hline \multirow{3}{*}{ TATA } & $t-2$ & -0.22 & 0.00 & 0.90 & \multirow{3}{*}{-1.76} & \multirow{3}{*}{0.08} & \multirow{3}{*}{-1.33} & \multirow{3}{*}{0.18} \\
\hline & $t-1$ & -0.10 & -0.07 & 0.25 & & & & \\
\hline & $t$ & -0.28 & -0.03 & 0.62 & & & & \\
\hline \multirow{3}{*}{ M-Score } & $t-2$ & 44.66 & -1.93 & 187.34 & \multirow{3}{*}{-3.93} & \multirow{3}{*}{0.00} & \multirow{3}{*}{-2.53} & \multirow{3}{*}{0.01} \\
\hline & $t-1$ & 5.15 & -2.38 & 36.44 & & & & \\
\hline & $t$ & -3.53 & -2.53 & 3.44 & & & & \\
\hline
\end{tabular}

Source: own study.

It is interesting, however, that both the computed mean and the median M-Score values for the periods for which no irregularities were detected ( $t-2$ and $t-1)$ are lower than the M-Score values for the $t$ period. This is further evidence reflecting the low usefulness of the eight-factor Beneish model in detecting accounting violations in the tested group of enterprises. Yet it seems that the obtained results were largely influenced by the low number of the tested sample.

\section{Conclusion}

The original Beneish model is presented in the accounting and financial literature as one of the most important tools for assessing the credibility of financial statements. Its relatively simple analytical formula and the reliance on economic figures generally available in the reported financial data allows for the view that it can be widely used in the decision-making process of various stakeholder groups, including 'wildcatters', banks, leasing and insurance companies.

The empirical research carried out among companies listed on the Warsaw Stock Exchange, which were sanctioned by the Polish Financial Supervision Authority for irregularities in the compliance with the IAS/IFRS guidelines, showed that the eight-factor Beneish model is of little use in the realities of the Polish capital market. The analyses highlighted the fact that in the selected research sample this model was only $40.74 \%$ effective in indicating manipulation of reporting data in period $t$, and $63.27 \%$ effective in showing no manipulation in periods $t-1$ and $t-2$. The proven low usefulness of the Beneish model in the detection of accounting violations (compared to other studies in this area) may be partially explained by the fact that the appropriate 
Beneish model was estimated on the basis of the reports of companies applying the GAAP principles. It can be assumed that the target solution is to build a new model, estimated on the basis of data from the Polish market, which would be a great support for statutory auditors, banks and auditors.

The presented research results cannot fulfill the condition of generalization. They contain partial results, opening up prospects for further research on evaluation and practical use of the available tools for detecting accounting violations. It should be clearly indicated that a relatively small group of enterprises was analysed in the paper because it is not easy to find information on irregularities in financial statements. The study recognizes the reports of the PFSA as one of the objective sources of this type of information. Moreover, even in the case of a positive opinion on the reliability of the financial statements, there is no guarantee that all the figures in the report were presented objectively.

\section{References}

Ahmed, T., and Naima, J. (2016). Detection and analysis of probable earnings manipulation by firms in a developing country. Asian Journal of Business and Accounting, 9(1), 59-81.

Anh N. H., and Linh N. H. (2016). Using the M-score model in detecting earnings management: evidence from non-financial Vietnamese listed companies VNU. Journal of Science: Economics and Business, 32(2), 14-23.

Arshad, R., Asyiqin, W. A., Razali, W. M., and Abu Bakar, N. (2015). Catch the "warning signals": The fight against fraud and abuse in non-profit organisations. Procedia Economics and Finance, 28, 114-120.

Beneish, M. D. (1999). The detection of earnings manipulation. Financial Analysts Journal, 55(5), 24-36.

Dalecka, A. (2015). Użyteczność modelu Beneisha w detekcji manipulacji księgowych. Finanse, Rynki Finansowe, Ubezpieczenia, 73(1), 1-9.

Dbouk, B., and Zaarour, I. (2017). Financial statements earnings manipulation detection using a layer of machine learning. International Journal of Innovation, Management and Technology, 8(3), 172-179.

Dechow, P. M, Ge, W., Larson, C. R., and Sloan, R. (2011). Predicting material accounting misstatements. Contemporary Accounting Research, 28(1), 17-82.

Dechow, P. M., and Dichev, I. D. (2002). The quality of accruals and earnings: the role of accrual estimation errors. The Accounting Review, 77(1), 35-59.

DiNapoli, T. P. (2016). Red flags for fraud. State of New York Office of the State Comptroller.

Fich, E. M., and Shivdasani, A. (2007). Financial fraud, director reputation, and shareholder wealth. Journal of Financial Economics, 86(2), 306-333.

Franceschetti, B. M., and Koschtial, C. (2013). Do bankrupt companies manipulate earnings more than the non-bankrupt ones? Journal of Finance and Accountancy, 12, 1-22.

Golec, A. (2019). Ocena skuteczności modelu Beneisha w wykrywaniu manipulacji w sprawozdaniach finansowych. Acta Universitatis Lodziensis. Folia Oeconomica, 2(341), 161-183.

Grove, H., and Basilico, E. (2008). Fraudulent financial reporting detection: Key ratios plus corporate governance factors. International Studies of Management \& Organization, 38(3), 10-42.

Healy, P. M., and Wahlen, J. M. (1999). A review of the earnings management literature and its implications for standard setting. Accounting Horizons, 13(4), 365-383. 
Jones, J. (1991). Earnings management during import relief investigations. Journal of Accounting Research, 29(2), 193-228.

Kaminski, K. A., Wetzel, T. S., and Guan, L. (2004). Can financial ratios detect fraudulent financial reporting? Managerial Auditing Journal, 19(1), 15-28.

Kaur, R., Sharma, K., and Khanna, A. (2014). Detecting earnings management in India - a sector-wise study on European. Journal of Business and Management, 6(11), 11-18.

Lew, A. (2017). Oszustwa księgowe w obszarze przychodów i kosztów wpływające na wiarygodny obraz jednostki gospodarczej wykrywane przez biegłego rewidenta. Prace Naukowe Uniwersytetu Ekonomicznego we Wrocławiu, 471, 300-308.

Mahama, M. (2015). Detecting corporate fraud and financial distress using the Altman and Beneish models. International Journal of Economics, Commerce and Management, 3(1), 1-18.

Marinakis, P. (2011), An investigation of earnings management and earnings manipulation in the UK, Doctoral dissertation, Nottingham University, UK, 2011.

Njanike, K., Dube, T., and Mashayanye, E. (2009). The effectiveness of forensic auditing in detecting, investigating, and preventing bank frauds. Journal of Sustainable Development in Africa, 10(4), 405-425.

Paolone, F., and Magazzino, C. (2014). Earnings manipulation among the main industrial sectors: Evidence from Italy. Economia Aziendale, 5, 253-261.

Polish Financial Supervision Authority [PFSA]. (2018). Wykaz kar nałożonych przez Komisje Nadzoru Finansowego za lata 2006 -2018. Retrieved from https://bip.knf.gov.pl/pliki/kary_ KNF_2006_2018_tcm6-65884.pdf.

Pincus, K. V. (1989). The efficacy of a red flags questionnaire for assessing the possibility of fraud. Accounting, Organizations and Society, 14(1-2), 153-163.

Piosik, A. (red.). (2013). Ksztattowanie zysków podmiotów sprawozdawczych w Polsce. MSR/MSSF a ustawa o rachunkowości. Warszawa: Wydawnictwo C.H. Beck.

Schipper, K. (1989). Commentary on earnings management. Accounting Horizons, 3(4), 91-103.

Skousen, Ch. J., and Twedt, B. J. (2009). Fraud score analysis in emerging markets. Cross Cultural Management: An International Journal, 16(3), 301-316.

Tarjo, Herawati, N. (2015). Application of Beneish M-score Models and data mining to detect financial fraud. Procedia - Social and Behavioral Sciences, 211, 924-930.

\section{SKUTECZNOŚĆ MODELU BENEISHA W WYKRYWANIU MANIPULACJI KSIĘGOWYCH NA PRZYKLADZIE SPÓŁEK UKARANYCH PRZEZ KOMISJE CADZORU FINANSOWEGO}

Streszczenie: Zasadniczym celem artykułu jest ocena skuteczności ośmioczynnikowego modelu Beneisha w wykrywaniu manipulacji w sprawozdaniach finansowych spółek publicznych notowanych na GPW w Warszawie. W badaniach przeanalizowano 27 przedsiębiorstw, które w okresie 2006-2018 zostały przynajmniej jeden raz ukarane przez KNF za nieprawidłowości w zakresie przestrzegania ram MSR/MSSF. W toku poczynionych analiz udowodniono, iż w tak dobranej próbie badawczej oryginalna wersja modelu Beneisha charakteryzuje się stosunkowo niewielkim stopniem przydatności, lecz powinna być uznana za narzędzie wspomagające pracę audytorów, biegłych rewidentów oraz inwestorów giełdowych i jednoczesnie punkt wyjścia w dalszym poszukiwaniu instrumentów służących do detekcji manipulacji finansowych, opracowanych z myślą o polskim rynku kapitałowym.

Słowa kluczowe: model Beneisha, spółki ukarane, Komisja Nadzoru Finansowego, Giełda Papierów Wartościowych w Warszawie, manipulacje księgowe. 